\title{
AN EXPERIMENTAL INVESTIGATION ON THE MODULUS OF ELASTICITY OF FIBER REINFORCED CONCRETE CONTAINING FLY ASH
}

\author{
A. Sofi, Gaurav Sharma, and Shakil Kumar \\ Structural and Geotechnical Division, School of Mechanical and Building Sciences, VIT University, Vellore, Tamilnadu, India \\ Email:sofime@gmail.com
}

\begin{abstract}
The use of fly ash in concrete today is an important subject and is growing in importance day by day. Using fly ash in concrete may provide both economical advantages and better properties in the production of concrete. Besides, concretes produced with different replacement ratios of fly ash is better than concrete to which other different types of fibers are added. This paper reports on the strength of concrete containing fly ash and various types of fibers like polypropylene fiber, glass fiber and steel fiber. The fly ash content used in this study was $0 \%, 10 \%$, and $20 \%$ in mass basis; the fiber content was $0 \%, 0.5 \%, 1.0 \%$ and $2.0 \%$ in volume basis. The modulus of elasticity based on stress-strain curve was determined for fly ash based fiber reinforced concrete. According to the results of the study, addition of fly ash and fibers improves concrete strength based on the modulus of elasticity values obtained.
\end{abstract}

Keywords: Concrete, Fly ash, Polypropylene fiber, Glass fiber, Steel fiber, Stress-strain curve, Modulus of elasticity.

\section{INTRODUCTION}

The collection and disposal of residues such as fly ash and sludge from various industrial operations has become a potent environmental problem. Fly ash is a residual material of energy production using coal, which was found to have numerous advantages for use in the concrete industry. Blending concrete with fly ash increases workability and ultimate strength and reduces permeability, bleeding and heat of hydration. However, the use of fly ash in concrete reduces the early strength. Fly ash from different thermal power plants has different characteristics [1]. One of the ways to compensate for the early-age strength loss in fly ash blended concrete is by incorporating fibers, which proved efficacious in enhancing the strength characteristics of concrete [2]. The addition of fibers to concrete considerably improves its structural characteristics such as static flexural strength, impact strength, tensile strength, ductility and flexural toughness [3]. Different types of fibers such as steel fibers, glass fibers etc., are used as inclusions in concrete. For long term strength and toughness and high stress resistance, steel fiber reinforced concrete (SFRC) is being used increasingly in civil engineering infrastructure such as flooring, housing, precast, tunnelling, heavy duty pavement and mining [4]. Generally, aspect ratios of steel fibers used in concrete mix are varied between 50 and 100 and suitable volume fraction values for concrete mixes are between $0.5 \%$ and $2.5 \%$ by volume of concrete [5]. Performance of fiber-reinforced 
concrete depends on the material and geometry of fiber [6]. It also depends on the way the fiber inclusions get distributed in the concrete matrix [7]. Further, fiber orientation and fiber concentration also influence the performance of fiber-reinforced concrete [8]. Fly ash concrete in-corporated with fibersincrease the durability properties of concrete [9]. Although, there were numerous studies carried out on the influence of fiber on mechanical and durability properties of concrete, there has been only a limited research concerning the influence of fiber addition in concrete with pozzolans. This work aims on to investigate the modulus of elasticity by using different types of fibers. Since three different types of fibers were used, the use of fly ash was limited to $10 \%$ and $20 \%$.

\section{EXPERIMENTAL INVESTIGATION}

\subsection{TEST MATERIALS}

\subsubsection{Cement}

Ordinary Portland cement of 53 grade was used (Table 1). The specific gravity of the cement was found to be 3.15. The initial cement and final setting times of cement were found to be 140 minutes and 245 minutes respectively.

\subsubsection{Fly ash}

The fly ash used was obtained from MetturThermal power station located in Salem District, Tamil Nadu. The specific gravity of the fly ash was found to be 2.5 (Table 1).

\subsubsection{Aggregate}

Aggregates of sizes $20 \mathrm{~mm}$ and $12 \mathrm{~mm}$ were used in this work. The specific gravity of coarse aggregate was found to be 2.78 and its water absorption was $0.5 \%$. The specific gravity of fine aggregate was 2.60 and its water absorption was $1.02 \%$.

\subsubsection{Fiber reinforcement}

Different types of fibers like polypropylene, steel and glass fibers were used (Table 2). The tensile strength of polypropylenefiber was found to be $2000 \mathrm{Mpa}$, glass fiber was found to be $1700 \mathrm{MPa}$, and steel fiber was found to be $1098 \mathrm{MPa}$.

\section{MIXTURE COMPOSITION AND PREPARATION}

For each cubic meter of concrete, w/cement+fly ash ratio given in Table 3 was adopted.Mixture design is made in accordance with the Indian Standard code 10262-2009 for M20 grade of concrete. Fresh concretes containing $10 \%$ and $20 \%$ fly ash as cement replacement in mass basis were prepared by modifying the reference Portland cement concrete. Fresh fiber reinforced concretes containing $0.5 \%, 1.0 \%$ and $2.0 \%$ of different fibers in volume basis were prepared. The procedures for mixing the fiber-reinforced concrete involved the following steps. First, the gravel and sand were placed in a concrete mixer and dry mixed for $1 \mathrm{~min}$. Second, the cement and fiber were spread out and drymixed for $1 \mathrm{~min}$. Third, the mixing water was added and mixed for approximately $2 \mathrm{~min}$. Finally, the freshly mixed fiber-reinforced concrete was cast into specimens mold and vibrated simultaneously to remove any entrapped air remaining. After casting, each of the specimens was allowed to stand for $24 \mathrm{~h}$ in laboratory before demolding.

Demolded specimens were stored in water at $23 \pm 2{ }^{\circ} \mathrm{C}$ until testing days.

TABLE 1: CHEMICAL COMPOSITION OF CEMENT AND FLY ASH (\%)

\begin{tabular}{|c|c|c|c|c|c|c|c|c|c|}
\hline Oxide & $\mathrm{SiO}_{2}$ & $\mathrm{Al}_{2} \mathbf{O}_{3}$ & $\mathrm{Fe}_{2} \mathrm{O}_{3}$ & $\mathrm{CaO}$ & $\mathbf{M g O}$ & $\mathbf{S O}_{3}$ & $\mathrm{~K}_{2} \mathbf{O}$ & $\mathrm{Na}_{2} \mathrm{O}$ & $\mathrm{LOI}$ \\
\hline Cement & 19.94 & 5.15 & 3.38 & 63.37 & 1.58 & 1.93 & 0.90 & 0.24 & 0.98 \\
\hline Fly ash & 54.46 & 33.11 & 1.76 & 7.97 & 0.35 & 1.20 & 0.00 & 0.00 & 2.16 \\
\hline
\end{tabular}


TABLE 2: PROPERTIES OF FIBER

\begin{tabular}{|c|c|c|c|}
\hline Fiber type & $\begin{array}{c}\text { Length } \\
(\mathbf{m m})\end{array}$ & $\begin{array}{c}\text { Diameter } \\
(\mathbf{m m})\end{array}$ & $\begin{array}{c}\text { Tensile strength } \\
\text { (MPa) }\end{array}$ \\
\hline $\begin{array}{c}\text { Polypropylene fiber } \\
\text { (PPF) }\end{array}$ & 12 & 0.025 & 326 \\
\hline Glass fiber (GF) & 12 & 0.014 & 1700 \\
\hline Steel fiber (SF) & 50 & 1 & 1098 \\
\hline
\end{tabular}

TABLE 3: TEST VARIABLES

\begin{tabular}{|c|c|c|c|c|}
\hline $\begin{array}{c}\text { Fly ash } \\
\text { content (\%) }\end{array}$ & \multicolumn{3}{|c|}{ Fiber type } & $\begin{array}{c}\text { water / } \\
\text { cement+fly }\end{array}$ \\
\hline \multirow{4}{*}{0} & $0 \% \mathrm{PPF}$ & $0 \% \mathrm{GF}$ & $0 \%$ SF & \multirow{4}{*}{0.45} \\
\hline & $0.5 \% \mathrm{PPF}$ & $0.5 \% \mathrm{GF}$ & $0.5 \% \mathrm{SF}$ & \\
\hline & $1 \% \mathrm{PPF}$ & $1 \% \mathrm{GF}$ & $1 \%$ SF & \\
\hline & $2 \% \mathrm{PPF}$ & $2 \% \mathrm{GF}$ & $2 \% \mathrm{SF}$ & \\
\hline \multirow{4}{*}{10} & $0 \% \mathrm{PPF}$ & $0 \% \mathrm{GF}$ & $0 \%$ SF & \multirow{4}{*}{0.46} \\
\hline & $0.5 \% \mathrm{PPF}$ & $0.5 \% \mathrm{GF}$ & $0.5 \% \mathrm{SF}$ & \\
\hline & $1 \% \mathrm{PPF}$ & $1 \% \mathrm{GF}$ & $1 \%$ SF & \\
\hline & $2 \% \mathrm{PPF}$ & $2 \% \mathrm{GF}$ & $2 \% \mathrm{SF}$ & \\
\hline \multirow{4}{*}{20} & $0 \% \mathrm{PPF}$ & $0 \% \mathrm{GF}$ & $0 \%$ SF & \multirow{4}{*}{0.47} \\
\hline & $0.5 \% \mathrm{PPF}$ & $0.5 \% \mathrm{GF}$ & $0.5 \% \mathrm{SF}$ & \\
\hline & $1 \% \mathrm{PPF}$ & $1 \% \mathrm{GF}$ & $1 \% \mathrm{SF}$ & \\
\hline & $2 \%$ PPF & $2 \% \mathrm{GF}$ & $2 \% \mathrm{SF}$ & \\
\hline
\end{tabular}

\section{TESTING METHOD}

The elastic modulus of cylindrical concrete specimens was determined according to ASTM C 469 [10]. Cylinders of dimensions $300 \mathrm{~mm}$ (height) and $150 \mathrm{~mm}$ (diameter) were used to determine the modulus of elasticity at 28 days of curing period. The specimen attached with the strain measuring equipment was placed under a compression testing machine. Load is applied gradually and the longitudinal strain is measured at equal interval of applied load. Stress-strain curve was plotted to obtain the elastic modulus of the concrete specimen and the fly ash specimen reinforced with fibers.

\section{TEST VARIABLES}

Cement was replaced by fly ash by two different percentages (10\% and 20\%) by weight. Steel fiber was also added at three different percentages of $(0.5 \%, 1 \%$, and $2 \%)$ by volume of concrete (Table3).

\section{RESULTS AND DISCUSSION}

In this study, elastic modulus was calculated from a stress-strain curve as shown in Figures 1-3 for $0 \%$ fly ash concrete specimens with variuous fiber content dosages. Similar curves were plotted for $10 \%$ and $20 \%$ fly ash concrete which has not been presented here. The elasticity modulus of the concretecontaining $10 \%$ and $20 \%$ fly ash was comparable with the elasticity modulus of reference Portland cement concrete at 28 days. The elastic modulus of concrete without fly ash containing $0.5 \%, 1 \%$ and $2 \%$ volume fraction of steel fiber is slightly higher than the elastic modulus of concrete without fibers. $10 \%$ and $20 \%$ of fly ash was added due to their pozzolanic behaviour in nature. The elastic modulus values are higher when fibers are added. (Table 4). Based on the experimental results it is observed that the modulus of elasticity of concrete without fly ash concrete specimen is found to have increased by $1.7 \%$ for $0.5 \% \mathrm{PPF}$, increased by $6.7 \%$ for $1 \% \mathrm{PPF}$, and by $12.96 \%$ for $2 \%$ PPF when compared to conventional concrete. When glass fibers are added to concrete specimen without fly ash the values seem to be increased by $2.5 \%$ for $0.5 \%$ GF, increased by $12.59 \%$ for $1 \% \mathrm{GF}$, and by $15.92 \%$ for $2 \%$ GF when compared to conventional concrete. When steel fibers are added the values increase by $25.82 \%$ for $0.5 \% \mathrm{SF}$, increased by $28.65 \%$ for $1 \% \mathrm{SF}$, and by $33.38 \%$ for $2 \%$ SF when compared to conventional concrete.

When $10 \%$ fly ash is added, the value of the modulus of elasticity of concrete increases by $2.25 \%$ for $0.5 \% \mathrm{PPF}$, increased by $8.56 \%$ for $1 \% \mathrm{PPF}$, and by 10.765 for $2 \%$ PPF when compared to fly ash specimen without fiber. 


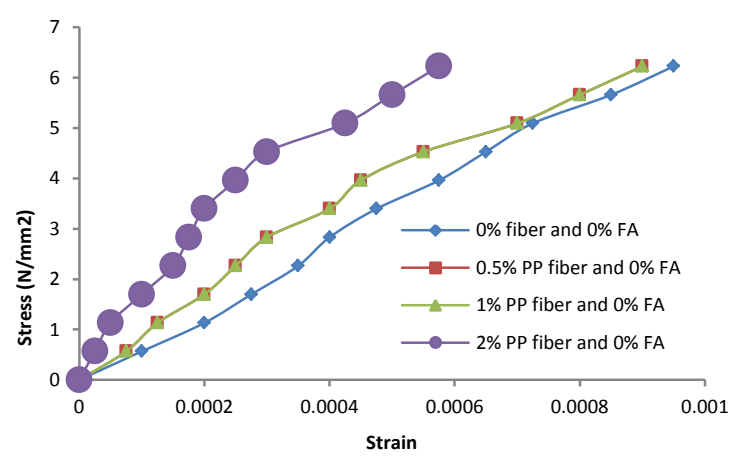

Fig.1. Stress-strain curve for conventional concrete with varying polypropylene fiber content

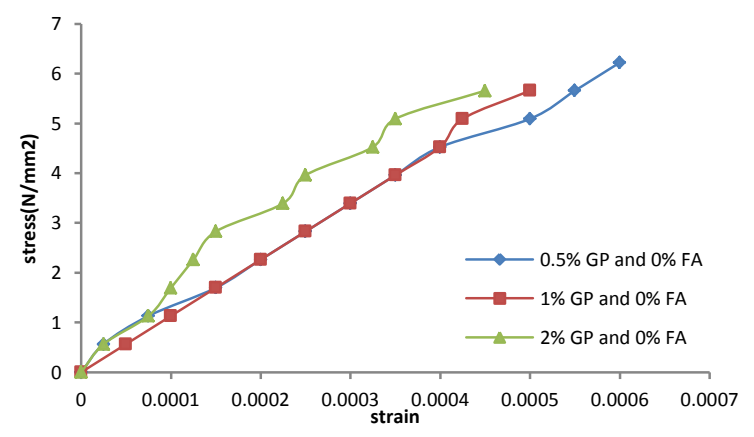

Fig.2. Stress-strain curve for conventional concrete with varying glass

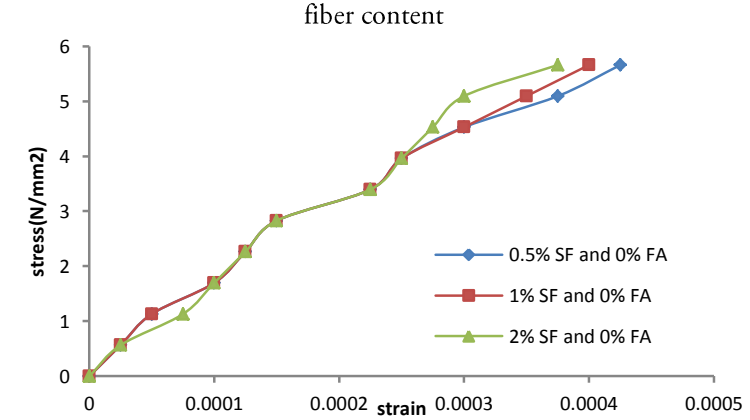

Fig.3. Stress-strain curve for conventional concrete with varying steel fiber content

TABLE 4: MODULUS OF ELASTICITY OF CONCRETE AT 28 DAYS

\begin{tabular}{|c|c|c|c|}
\hline \multirow{2}{*}{ Fiber type } & \multicolumn{3}{|c|}{ Elastic Modulus (GPa) } \\
\cline { 2 - 4 } & $\mathbf{0 \%}$ & $\mathbf{1 0 \%}$ & $\mathbf{2 0 \%}$ \\
\hline $0 \% \mathrm{PPF}$ & 12.35 & 13.02 & 14.19 \\
\hline $0.5 \% \mathrm{PPF}$ & 12.14 & 13.32 & 14.34 \\
\hline $1 \% \mathrm{PPF}$ & 13.24 & 14.24 & 14.66 \\
\hline $2 \% \mathrm{PPF}$ & 14.19 & 14.59 & 15.23 \\
\hline $0.5 \% \mathrm{GF}$ & 12.67 & 13.64 & 14.64 \\
\hline $1 \% \mathrm{GF}$ & 14.13 & 14.41 & 15.47 \\
\hline $2 \% \mathrm{GF}$ & 14.69 & 14.87 & 16.06 \\
\hline $0.5 \% \mathrm{SF}$ & 16.65 & 19.23 & 21.14 \\
\hline $1 \% \mathrm{SF}$ & 17.31 & 19.89 & 22.46 \\
\hline $2 \% \mathrm{SF}$ & 18.54 & 20.56 & 24.45 \\
\hline
\end{tabular}

When glass fibers are added for $10 \%$ fly ash concrete specimens the value increases by $4.54 \%$ for $0.5 \% \mathrm{GF}$, increased by $9.64 \%$ for $1 \% \mathrm{GF}$, and by $12.44 \%$ for $2 \%$ GF when compared to fly ash specimen without fiber. When steel fibers are added for $10 \%$ fly ash concrete specimens the value increases by $32.29 \%$ for $0.5 \% \mathrm{SF}$, incresed by $34.54 \%$ for $1 \% \mathrm{SF}$, and by $36.67 \%$ for $2 \%$ SF when compared to flyash specimen without fiber. For 20\% fly ash concrete specimens the value increases by $1.05 \%$ for $0.5 \% \mathrm{PPF}$, incresed by $3.20 \%$ for $1 \% \mathrm{PPF}$, and by $6.82 \%$ for $2 \% \mathrm{PPF}$ when compared to fly ash specimen without fiber. When glass fibers are added the values increase by $3.07 \%$ for $0.5 \%$ GF, increased by $8.27 \%$ for $1 \%$, and by $11.64 \%$ for $2 \%$ when compared to fly ash specimen without fiber. When steel fibers are added the values increase by $32.25 \%$ for $0.5 \% \mathrm{SF}$, increased by $36.85 \%$ for $1 \% \mathrm{SF}$, and by $41.96 \%$ for $2 \%$ SF when compared to fly ash specimen without fiber.

\section{CONCLUSION}

The study is carried out to utilize fly ash as a partial replacement of cement, since fly ash is pozzolanic in nature the strength of concrete specimen in terms of modulus of concrete seems to increase when compared to concrete without flyash. When compared to the above mentioned fibers the modulus of elasticity of steel fiber reinforced concrete specimens seems to be higher than polypropylene fiber and glass fiber. This may be due to the property of the material.

\section{REFERENCES}

[1] R. Siddique"Properties of concrete incorporating high volumes of class F fly ash and san fibers", Cement Concrete Res 2004, 34: pp. 37-42.

[2] Y. Mohammadi, S.P. Singh, S.K. Kaushik. "Properties of steel fibrous concrete containing mixed fibers in fresh and hardened state", Constr Build Mater, in press, doi: 10.1016/ j. conbuildmat, 2006, pp.12.004. 
[3] S.Yazıc1, G.Inan, V.Tabak. "Effect of aspect ratio and volume fraction of steel fiber on the mechanical properties of SFRC". Constr Build Mater 2007,21, pp. 1250-3.

[4] R.F.Zollo. "Fiber-reinforced concrete: an overview after 30 years of development". Cement Concrete Comp 1997,19, pp. 107-22.

[5] I.B.Topcu, M. Canbaz. "Effect of different fibers on the mechanical properties of concrete containing fly ash”. Constr Build Mater 2007,21, pp. 1486-91.

[6] C.X.Qian, P.Stroeven. "Development of hybrid polypropylene-steel fiber-reinforced concrete". Cement Concrete Res 2000, pp. 30:63-9.
[7] R.M.Gutierrez, L.N.Diaz, S.Delvasto. "Effect of pozzolans on the performance of fiber-reinforced mortars". Cement Concrete Comp 2005,27, pp. 593-8.

[8] O.Eren, T.Celik. "Effect of silica fume and steel fibers on some properties of high-strength concrete". Constr Build Mater 1997,11, pp.37382.

[9] S.F.H.Ahmed, M.Maalej, P.Paramasivam. "Flexural responses of hybrid steel-polyethylene fiber reinforced cement composites containing high volume fly ash". Constr Build Mater 2007, 21, pp. 1088-97.

[10] ASTM C469-02. "Test method for static modulus of elasticity and poisson's ratio of concrete in compression”. Annual Book of ASTM Standards, 2005 
دراسة معملية لمعامل المرونة للخرسانة المسلحة المحتوية على الرماد المتطاير

$$
\text { قسم الهندسة الهدنية، معهد فيلور للتكنولوجيا، تاميل نادو، الهند }
$$

الملخص:

إن إستخدام الرماد المنطاير في الخرسانة المسلحة هو موضوع هام و يزداد أهمية يوما بعد يوم. فإن استخدام الرماد المنطاير في الخرسانة قد يوفر مز ايا اقتصادية و خصائص أفضل في إنتاج الخرسانة على حد سو اء. الى جانب ذلك، فإن الخرسانة المنتجة مع نسب استبدال مختلفة من الرماد المنطاير ، أفضل من أنواع مختلفة مضافا إليها أنواع أخرى من الألياف. هذا البحث توضح قوة الخرسانة التي تحتوي على الرماد المنطاير و أنواع مختلفة من الألياف مثل ألياف البولي بروبلين و الألياف الزجاجية و الألياف الصلب. وفي هذه الدر اسة كانت نسب الرماد المنطاير المستخدم هي 0 \%؛ 10 ٪ ، و 20 ٪ على أساس الكتلة، و كان محتوى الألياف 0\% ، 0.5 ٪ ، 1.0 \% و 2.0 ٪ على أساس الحجم.ثم تم تحديد معامل المرونة على أساس منحنى الإجهاد والانفعال. ووفقا لنتائج الدر اسة فإن إضافة الرماد المتطاير والألياف نوفر أداء أفضل للخرسانة وتحسين قوتها. 